\title{
Evolution of the mineral fertility of an acidic soil during a period of ten years in the Vosges mountains (France). Impact of humus mineralisation
}

\author{
Maurice BONNEAU* \\ INRA Centre de Nancy - Cycles biogéochimiques, 54280 Champenoux, France
}

(Received 12 December 2003; accepted 7 June 2004)

\begin{abstract}
A very acidic soil under an adult spruce (Picea abies) stand, in the Basses-Vosges (North-eastern France), was analysed in 1986, and ten years later in 1996. The chemical composition of the mineral horizons did not show much variation, but the sum of exchangeable Ca and $\mathrm{Mg}$ in the mineral horizons and their total contents in the $\mathrm{OL}, \mathrm{OF}$ and $\mathrm{OH}$ horizons decreased significantly. In ten years, the Mg in particular had decreased by about $30 \mathrm{~kg} \cdot \mathrm{ha}^{-1}$, i.e. about $1.7 \%$ per year of the exchangeable $\mathrm{Mg}$ present in 1986 . This decrease, which is worrying for the future, may be explained by peaks of humus mineralisation during warm summers combined with the inability of the mineral horizons, highly saturated in aluminium, to retain $\mathrm{Ca}$ and $\mathrm{Mg}$ coming from this mineralisation in the organic horizons. As a result, these elements were lost in drainage water instead of being taken up by the roots. As this soil was poor in weatherable minerals, the loss could not be compensated for by mineral decomposition. It is probable that a similar situation occurs at the end of a forest rotation when organic horizons are exposed to light and heat. Thus, the degradation of the humus from mull to dysmoder, followed by mineralisation, together with a high exchangeable Al content in mineral horizons and acid rain, all lead to losses of $\mathrm{Mg}$ and secondarily $\mathrm{Ca}$ at different stages of development of forest stands on acidic soils. Thus humus mineralisation, combined with a high exchangeable Al content, is one of the key mechanisms of soil acidification and impoverishment.
\end{abstract}

aluminium / chemical fertility / climate / humus / soil acidification

Résumé - Évolution de la fertilité minérale d'un sol acide sur une période de 10 ans dans les Vosges (France). Impact sur la minéralisation de l'humus. Un sol très acide des Basses Vosges (Nord-Est de la France), sous un peuplement d'épicéa adulte, a été analysé en 1986, puis en 1996. La composition chimique des horizons minéraux n'a que peu varié, mais la somme du calcium et du magnésium échangeables des horizons minéraux et totaux des horizons OL, OF et $\mathrm{OH}$ a diminué significativement, surtout celle de Mg qui a baissé de $30 \mathrm{~kg} \cdot \mathrm{ha}^{-1}$ en dix ans, soit environ 1,7\% par an du magnésium échangeable présent en 1986. Cette diminution, préoccupante pour l'avenir, peut s'expliquer par un pic de minéralisation de l'humus pendant les étés chauds combiné avec l'incapacité des horizons minéraux, fortement saturés en aluminium, à retenir le calcium et le magnésium provenant de la minéralisation des couches d'humus. Ces éléments sont donc perdus par drainage au lieu d'être prélevés par les racines. Dans ce sol, pauvre en minéraux altérables, cette perte ne peut pas être compensée par l'altération. Une telle situation se produit certainement aussi en fin de révolution, lorsque les horizons humifères sont exposés à la lumière et à la chaleur. Ainsi, la dégradation de l'humus de mull en dysmoder et, plus tard, sa minéralisation, couplée avec une forte teneur des horizons minéraux en aluminium échangeable, conduit à de fortes pertes de magnésium et, secondairement, de calcium, à différents stades de développement des peuplements forestiers en sol acide. L'association de ces deux facteurs peut être considérée comme un des mécanismes-clé de l'acidification des sols et de leur appauvrissement.

aluminium / fertilité chimique / climat / humus / acidification du sol

\section{INTRODUCTION}

Forest soil acidification has been well documented during the last two decades [3, 6, 10,12-14, 19-21]. This phenomenon is generally attributed to acid inputs in forests by rain precipitation or dry deposition which lead to an exchange between $\mathrm{H}^{+}$ ions in the throughfall and $\mathrm{Ca}, \mathrm{Mg}$ or $\mathrm{K}$ ions on the exchange complex. This results in a decrease in soil saturation by these basic cations and an increased $\mathrm{Al}$ content which in turn prevents sorption on the exchange complex of $\mathrm{Mg}$ and $\mathrm{Ca}$ coming from external (dust) or internal sources (humus mineralisation, mineral weathering) [9]. Another cause of soil acidification is the nitrogen cycle, particularly nitrification of ammonium from external or internal sources [17, 22].

On the other hand, soil acidification may be considered either as a pH decrease, accompanying lower soil base saturation,

* Corresponding author: maurice.Bonneau@wanadoo.fr

Present address: 4 rue de Bastogne, 54500 Vandœuvre-lès-Nancy, France. 
Table I. Soil properties. Samples were taken in a soil pit at the edge of the study plot. Exchange complex was determined at soil $\mathrm{pH}$. $\mathrm{P}_{2} \mathrm{O}_{5}$ was determined by the Duchaufour method (two successive extractions with $\mathrm{H}_{2} \mathrm{SO}_{4} 0.004 \mathrm{~N}$ and $\mathrm{OHNa} 0.01 \mathrm{~N}$ ).

\begin{tabular}{|c|c|c|c|c|c|c|c|c|c|c|c|c|c|}
\hline & \multicolumn{5}{|c|}{ Particle size (\%) } & \multirow{2}{*}{$\begin{array}{c}\begin{array}{c}\text { Total } \\
\text { org. C }\end{array} \\
\%\end{array}$} & \multirow[t]{2}{*}{$\mathrm{C} / \mathrm{N}$} & \multicolumn{5}{|c|}{$\begin{array}{l}\text { Exchange complex } \\
\quad\left(\mathrm{cmol}^{+} \cdot \mathrm{kg}^{-1}\right)\end{array}$} & \multirow{2}{*}{$\begin{array}{c}\text { Bioav } \\
\mathrm{P}_{2} \mathrm{O}_{5}\end{array}$} \\
\hline & Clay & $\begin{array}{c}\text { Fine } \\
\text { silt }\end{array}$ & $\begin{array}{c}\text { Coarse } \\
\text { silt }\end{array}$ & $\begin{array}{l}\text { Fine } \\
\text { sand }\end{array}$ & $\begin{array}{c}\text { Coarse } \\
\text { sand }\end{array}$ & & & $\begin{array}{l}\text { C.E.C. } \\
\text { at } \mathrm{pH} 7\end{array}$ & $\mathrm{Ca}$ & $\mathrm{Mg}$ & $\mathrm{K}$ & $\mathrm{Al}$ & \\
\hline $\begin{array}{l}\overline{\mathrm{OH}} \\
3-0 \mathrm{~cm}\end{array}$ & - & - & - & - & - & 20.5 & 20.4 & 37.1 & 1.2 & 0.49 & 0.56 & 9.4 & - \\
\hline $\begin{array}{l}\text { A } \\
0-5 \mathrm{~cm}\end{array}$ & - & - & - & - & - & 7.0 & 17.8 & 21.1 & 0.2 & 0.16 & 0.22 & 7.4 & - \\
\hline $\begin{array}{l}\mathrm{A} / \mathrm{B} \\
5-20 \mathrm{~cm}\end{array}$ & 18.9 & 29.1 & 10.5 & 15.5 & 26.0 & 3.1 & 15.5 & 12.9 & 0.1 & 0.06 & 0.12 & 5.1 & 0.17 \\
\hline $\begin{array}{l}\mathrm{S} \\
20-40 \mathrm{~cm}\end{array}$ & 16.3 & 27.6 & 14.6 & 17.3 & 24.2 & 1.8 & 15.8 & 9.2 & 0.1 & 0.02 & 0.07 & 3.7 & 0.36 \\
\hline $\begin{array}{l}\mathrm{S} / \mathrm{C} \\
40-75 \mathrm{~cm}\end{array}$ & 14.9 & 24.9 & 15.2 & 18.3 & 26.7 & & & 6.8 & $<0.1$ & 0.01 & 0.07 & 5 to 6 & - \\
\hline
\end{tabular}

or as a decrease in Acid Neutralization Capacity (ANC), that is the difference between the sum of all the cations in soil $(\mathrm{Ca}$, $\mathrm{Mg}, \mathrm{K}, \mathrm{Al}, \mathrm{Fe}, \mathrm{Mn}$ in minerals, in an exchangeable form or in the humus) and the acidic anions $\left(\mathrm{SO}_{3}, \mathrm{P}_{2} \mathrm{O}_{5}, \mathrm{Cl}\right)$ [22]. In very acidic soils, it is possible that soil base saturation and $\mathrm{pH}$ decreases are difficult to detect, or very low, while ANC still progresses considerably. It was also pointed out that the soil solution may provide a better indication of soil acidification than base saturation $[14,18]$.

The evolution of the soil $\mathrm{Ca}$ and $\mathrm{Mg}$ contents can be modelled from inputs (wet deposition, dry deposition, mineral weathering) and outputs (immobilisation in biomass, drainage). These data are not usually very accurate, and so a direct measurement of changes in total and exchangeable elements is necessary. Poszwa [16] and Dambrine et al. [3] compared the calculated and measured decrease of base saturation in the soil of the Strengbach catchment (Vosges), and indicated that results were similar for exchangeable calcium, but that, as far as magnesium was concerned, the actual loss was higher than the calculated one.

We set out to verify these phenomena using a "soil quality observation plot" which had been set up in 1986, within the framework of the DEFORPA Programme (Dépérissement des forêts attribué à la pollution atmosphérique). The soil of this observation plot was analysed in 1986 and again in 1996, and the results were compared with a nutrient balance in the forest ecosystem. As a result of that comparison, an acidification process which had not yet been identified came to light.

\section{MATERIALS AND METHODS}

The site studied was located in plot 75 of the DONON State Forest (Bas-Rhin, East of France, Lambert I coordinates 953770.21 N $\times$ $99575.68 \mathrm{E}$, altitude $710 \mathrm{~m}$ ). Mean pluviometry is about $800 \mathrm{~mm}$ and annual mean temperature $7.5^{\circ} \mathrm{C}$. The spruce stand was 95 years old at the beginning of the study in 1986, and had been planted in a former beech stand. The soil was an acidic brown soil (Umbric Dystrochrept according to Soil Taxonomy, or a District Cambisol according to the W.R.B.), developed in a diluvium of Devonian volcanic rock. Soil tex- ture was a loam, water $\mathrm{pH}$ ranged from 4 to 4.5 , with a C.E.C. of about $11 \mathrm{cmol}^{+} \cdot \mathrm{kg}^{-1}$ (measured at soil $\mathrm{pH}$ ) in the A horizon, and $4 \mathrm{cmol}^{+} \cdot \mathrm{kg}^{-1}$ in deeper soil horizons. $(\mathrm{Ca}+\mathrm{Mg}+\mathrm{K}) /$ C.E.C. ratio was 0.09 in the A horizon, and 0.02 at a depth of $35 \mathrm{~cm}$ (Tab. I). The humus form was a dysmoder $[2,11]$ with a $2 \mathrm{~cm}$ thick OL layer, an OF layer ranging from 2 to $3 \mathrm{~cm}$ and an $\mathrm{OH}$ layer of 1 to $3 \mathrm{~cm}$, depending on the location. $\mathrm{C} / \mathrm{N}$ ratio was 20.4 in the $\mathrm{OH}$ layer, and decreased to 17.8 in the $\mathrm{A}$ horizon and 15.8 in the mineral horizons. The mineral horizons were very rich in exchangeable aluminium as indicated by the low $(\mathrm{Ca}+$ $\mathrm{Mg}+\mathrm{K}) /$ C.E.C. ratio, and demonstrated by direct measurement of exchangeable $\mathrm{Al}$ (Tab. I).

The soil reserve in weatherable minerals was very low; they were present only in large $(>10 \mathrm{~cm})$ unaltered blocks.

The study began in 1986. Six levels of the soil were sampled at 25 points selected from the 42 points of a $10 \times 10 \mathrm{~m}$ systematic grid. The following measurements ware made:

- in OL, OF, OH layers: total contents of $\mathrm{Ca}, \mathrm{Mg}, \mathrm{K}, \mathrm{C}, \mathrm{N}, \mathrm{S}, \mathrm{P}$, $\mathrm{Cd}, \mathrm{Co}, \mathrm{Cr}, \mathrm{Cu}, \mathrm{Ni}, \mathrm{Pb}, \mathrm{Zn}$.

- at depth of $0-5,8-18,25-35 \mathrm{~cm}$ in the mineral soil: total contents of $\mathrm{C}, \mathrm{N}, \mathrm{S}, \mathrm{Cd}, \mathrm{Co}, \mathrm{Cr}, \mathrm{Ni}, \mathrm{Pb}, \mathrm{Zn}$; exchangeable $\mathrm{Ca}, \mathrm{Mg}, \mathrm{K}$ and $\mathrm{Al}$ extracted using $\mathrm{NH}_{4} \mathrm{Cl}$ and determined by atomic absorption spectrometry; $\mathrm{P}_{2} \mathrm{O}_{5}$ extracted in $2 \%$ citric acid (in the first soil analysis (Tab. I), $\mathrm{P}_{2} \mathrm{O}_{5}$ was determined using the Duchaufour method, double extraction with $\mathrm{H}_{2} \mathrm{SO}_{4}$ and $\mathrm{OHNa}$ ) and colorimetry.

Statistical analysis of the 1986 results showed that the effect of time between 1986 and 1996 would be described more accurately if two groups of seven points (two blocks) containing the most homogeneous soil properties were considered. Thus, ten years later, in 1996, the samples were only taken from 14 points, one metre from those collected in 1986, and analysed. In addition, three replicates (triplets) were collected from four sampling points to test short distance spatial variation to be taken into account in the 1996/1986 comparison. The dry weight of fine earth $(<2 \mathrm{~mm})$ at 12 points including two replicates of three points were also measured.

The same analyses as those used in 1986 were carried out, using the same analytical methods, except for total elements in OL, OF and $\mathrm{OH}$ for which mineralisation by combustion was replaced by acid digestion in $\mathrm{HNO}_{3}$.

In order to eliminate analytical drift, all 1986 OL, OF and OH samples were re-analysed for total elements using the new $\mathrm{HNO}_{3}$ method. For exchangeable and bioavailable elements, all 1996 and 1986 samples were re-analysed using the same method as in 1986. For several exchangeable or bioavailable elements in the 1986 samples, the 1986 
Table II. Comparison between analytical results of the 1986 samples. Old: 1986 analyses. New: analyses repeated in 1996. Results are expressed in $\mathrm{cmol}^{+} \cdot \mathrm{kg}^{-1}$ for exchangeable elements and in $\mathrm{g} \cdot \mathrm{kg}^{-1}$ for bioavailable $\mathrm{P}_{2} \mathrm{O}_{5}$.

\begin{tabular}{lcc}
\hline Element & Old 1986 results & New 1986 results \\
\hline Exchangeable $\mathrm{Ca}$ & 0.26 & 0.18 \\
Exchangeable $\mathrm{Mg}$ & 0.20 & 0.34 \\
Exchangeable $\mathrm{K}$ & 0.18 & 0.22 \\
Exchangeable $\mathrm{Mn}$ & 0.16 & 0.55 \\
Exchangeable $\mathrm{Fe}$ & 0.04 & 0.13 \\
Exchangeable $\mathrm{Al}$ & 7.55 & 6.60 \\
Bioavailable $\mathrm{P}_{2} \mathrm{O}_{5}$ & 0.034 & 0.055 \\
(extracted by $2 \%$ citric acid) & & \\
\hline
\end{tabular}

and 1996 results were slightly different, suggesting that the chemical composition of these samples had evolved during ten years of stockage. This phenomenon was also mentioned by Falkengren-Grerup [8].

Table II shows the results of the 1986 and 1996 analyses of the 1986 samples. Finally, the results used for the 1986 samples in the statistical analysis were those obtained in 1996 for total contents and those obtained in 1986 for exchangeable and bioavailable elements.

In addition it was observed that workers operating in the second block of seven points in 1996 had sampled a little less OH material than those operating in the first block and in the two blocks in 1986. In order to compare the values of OH mass obtained in 1986 and 1996 correctly, as well as the chemical composition of the A horizon (because a little $\mathrm{OH}$ material was sampled with $\mathrm{A}$ ), the weight of the $\mathrm{OH}$ sampled in the second block was multiplied by 1.2 and A horizon element contents were corrected using the following formula:

Corrected A horizon content $=$ initial content $\times 1.046$

$$
-\mathrm{OH} \text { concentration } \times 0.046 \text {. }
$$

From 1993 to 1996, the precipitation was collected in open grassland near the study site, and throughfall in two $20 \times 20 \mathrm{~cm}$ under canopy rain gauges. Drainage water was collected at a depth of $60 \mathrm{~cm}$, in zero-tension lysimeters. The element contents of the precipitation and soil solutions made it possible to calculate input and output fluxes to calculate the soil budget.

Needle litter in ten litter traps was collected and analysed every third month from 1990 to 1995 . Element contents in this litter were used to calculate element immobilisation in the increasing needle biomass following needle loss during "forest decline" (1984-1986).

\section{Statistical interpretation}

We considered the differences between the 1986 and 1996 results to be significant if:

- they were significant in a two block test taking into account the seven individual results in each block;

- they were 1.96 higher than the mean standard deviation in the four triplets ; i.e. the interannual variation was higher than the short distance variability recorded in 1996.

\section{RESULTS}

The results are given in Tables III and IV.

\subsection{Mass of $\mathrm{OL}, \mathrm{OF}$ and $\mathrm{OH}$ layers and total element concentration}

The OL layer mass decreased between 1986 and 1996, but this variation was not significant. However the block test was positive and the 1986-1996 decrease was not much lower than the local variation $(0.44-0.56)$. Thus a real decrease is possible, and could be interpreted as a consequence of a longer needle retention after the forest decline of 1983-1988. More needles fell during this period, but then the trees recovered a normal needle biomass by reducing needle fall.

The OF layer mass remained approximately unchanged, but that of $\mathrm{OH}$ decreased significantly in the block test and in comparison with the local variation. This decrease could have been caused by high organic matter mineralisation during the hot summers of 1990, 1991 and 1992.

With respect to element concentration, $\mathrm{Pb}$ and $\mathrm{Cr}$ concentrations decreased significantly in $\mathrm{OL}$, that of $\mathrm{Pb}$ decreased significantly in OF (the block test was significant and the difference was only slightly lower than the standard deviation of the triplets), certainly as a consequence of using unleaded fuel. $\mathrm{K}$ increased and $\mathrm{Cr}$ decreased in $\mathrm{OF}$, and $\mathrm{P}$ increased in $\mathrm{OH}$.

\subsection{Element concentrations in the mineral horizons}

Water $\mathrm{pH}$ did not change in any horizon, but $\mathrm{KCl} \mathrm{pH}$ decreased in the A horizon $(0-5 \mathrm{~cm})$, whereas exchangeable $\mathrm{Mg}$ and $\mathrm{K}$ increased. The increase in $\mathrm{Mg}$ concentration probably resulted from $\mathrm{OH}$ mineralisation. $\mathrm{Ca}$ and $\mathrm{H}$ decreased in the 8-18 cm layer ( $\mathrm{S}$ horizon). $\mathrm{KCl} \mathrm{pH}$ increased slightly in the 25-35 cm layer while exchangeable $H$ decreased.

Finally it appeared that there were few, and insignificant changes in element concentrations. Short-term soil chemical fertility was not impaired between 1986 and 1996.

\subsection{Evolution of the total quantities of $K$, $\mathrm{Ca}$ and Mg in the soil}

Exchangeable elements are the bioavailable forms for tree nutrition, when a short period is considered. If a longer period is considered, it is clear that total elements in the organic layers are subjected to mineralisation and evolution into exchangeable elements, and will thus be able to play an important role in the mineral nutrition of trees in the future. We therefore calculated the evolution of $\mathrm{Ca}, \mathrm{Mg}$ and $\mathrm{K}$ from 1986 to 1996 considering the sum of total forms in the organic layers and exchangeable forms in the mineral horizons at depth of 0 to $35 \mathrm{~cm}$.

The results are shown in Table V. Both total $\mathrm{Ca}$ and $\mathrm{Mg}$ decreased considerably in the humus layers (83.9 and $115.9 \mathrm{~kg} \cdot \mathrm{ha}^{-1}$ respectively in 1996 , compared with 98.1 and 161.2 in 1986), whereas $\mathrm{K}$ decreased slightly. Exchangeable $\mathrm{Mg}$ increased slightly in the mineral horizons, whereas $\mathrm{Ca}$ decreased a little and $\mathrm{K}$ increased.

In conclusion, if we consider the sum of the humus layers and mineral horizons, $23 \mathrm{~kg} \cdot \mathrm{ha}^{-1} \mathrm{Ca}$ and $31 \mathrm{~kg} \cdot \mathrm{ha}^{-1} \mathrm{Mg}$ were lost from 1986 to 1996 , which represented about $16 \%$ and $18 \%$ of the total 1986 stocks respectively. The increase in the K stock amounted to $13 \%$ in the same period. 
Table III. Significant differences in organic layers. The 1996-1986 difference is in bold type when significant in the block interpretation. The value of 1.96 triplet standard deviation is noted only when the 1996-1986 difference in the block interpretation is significant. This value is in bold type when lower than the absolute value of the 1996-1986 difference.

\begin{tabular}{|c|c|c|c|c|c|}
\hline Feature & 1986 & 1996 & $\begin{array}{c}\text { 1986-1996 } \\
\text { difference }\end{array}$ & $\begin{array}{l}\text { Triplet standard } \\
\text { deviation } \\
\times 1.96\end{array}$ & $\begin{array}{l}\text { Significant } \\
\text { change }\end{array}$ \\
\hline \multicolumn{6}{|c|}{ OL } \\
\hline Mass $\mathrm{kg} \cdot \mathrm{m}^{-2}$ & 1.44 & 1.00 & -0.44 & 0.56 & no \\
\hline Total Ca $\mathrm{g} \cdot \mathrm{kg}^{-1}$ & 2.44 & 2.70 & +0.26 & & no \\
\hline Total Mg g. $\mathrm{kg}^{-1}$ & 0.31 & 0.40 & +0.09 & 0.31 & no \\
\hline Total $\mathrm{K}$ g.kg ${ }^{-1}$ & 0.77 & 0.83 & +0.06 & & no \\
\hline Total P & 0.86 & 0.84 & -0.02 & & no \\
\hline Total $\mathrm{Pb} \mathrm{mg} \cdot \mathrm{kg}^{-1}$ & 64.7 & 35.2 & -29.5 & 16.0 & yes \\
\hline Total Cd mg.kg ${ }^{-1}$ & 0.38 & 0.33 & -0.05 & & no \\
\hline Total Cr mg $\cdot \mathrm{kg}^{-1}$ & 2.13 & 1.03 & -1.10 & 0.71 & yes \\
\hline \multicolumn{6}{|c|}{ OF } \\
\hline Mass $\mathrm{kg} \cdot \mathrm{m}^{-2}$ & 1.77 & 2.62 & +0.85 & 1.48 & no \\
\hline Total Ca $\mathrm{g} \cdot \mathrm{kg}^{-1}$ & 1.99 & 1.50 & -0.49 & & no \\
\hline Total Mg g $\cdot \mathrm{kg}^{-1}$ & 0.57 & 1.03 & +0.46 & 2.76 & no \\
\hline Total $\mathrm{K}$ g.kg ${ }^{-1}$ & 0.65 & 1.04 & +0.39 & 0.25 & yes \\
\hline Total P & 0.94 & 0.99 & +0.05 & & no \\
\hline Total $\mathrm{Pb} \mathrm{mg} \cdot \mathrm{kg}^{-1}$ & 143 & 103 & -40 & 40.66 & no \\
\hline Total Cd mg.kg-1 & 0.38 & 0.28 & -0.10 & 0.12 & no \\
\hline Total Cr mg $\cdot \mathrm{kg}^{-1}$ & 3.00 & 1.84 & -1.16 & 0.88 & yes \\
\hline \multicolumn{6}{|c|}{$\mathrm{OH}$} \\
\hline Mass $\mathrm{kg} \cdot \mathrm{m}^{-2}$ & 7.26 & 4.10 & -3.16 & 2.60 & yes \\
\hline Total Ca $\mathrm{g} \cdot \mathrm{kg}^{-1}$ & 0.43 & 0.49 & +0.06 & & no \\
\hline Total Mg g $\cdot \mathrm{kg}^{-1}$ & 1.99 & 1.65 & -0.34 & & no \\
\hline Total $\mathrm{K} \mathrm{g} \cdot \mathrm{kg}^{-1}$ & 1.33 & 1.63 & +0.30 & 0.41 & no \\
\hline Total P & 0.94 & 1.12 & +0.18 & 0.15 & yes \\
\hline Total $\mathrm{Pb} \mathrm{mg} \cdot \mathrm{kg}^{-1}$ & 117 & 145 & +28 & 55.7 & no \\
\hline Total Cd mg. $\mathrm{kg}^{-1}$ & 0.15 & 0.17 & +0.02 & & no \\
\hline Total Cr mg $\cdot \mathrm{kg}^{-1}$ & 4.53 & 3.53 & -1.00 & & no \\
\hline
\end{tabular}

\section{DISCUSSION}

How can this decrease in $\mathrm{Ca}$ and $\mathrm{Mg}$ be explained? In order to answer that question, the quantities of $\mathrm{Ca}, \mathrm{Mg}$ and $\mathrm{K}$ incorporated in the woody biomass and the increasing needle biomass (as explained in the section on "mass of OL, OF, and OH layers") from 1986 to 1996 were estimated carefully. Ca and $\mathrm{Mg}$ inputs in wet and dry deposition were calculated, element concentrations in drainage water were measured, and element releases from soil minerals were estimated. Finally reliable balance limits for these elements were calculated.

Precipitation and throughfall were collected and analysed as described in the section on "materials and methods". Dry deposition was calculated, using the method of Dambrine and Prevosto [4], to be $80 \%$ of the difference between throughfall and precipitation in open grassland for $\mathrm{Ca}, 50 \%$ for $\mathrm{Mg}$ and $10 \%$ for $\mathrm{K}$. Total deposition was calculated by adding dry deposition and precipitation deposition, assuming that these three elements were not directly absorbed by needles (it is known that elements other than nitrogen are not absorbed at all or very little).

Mineral weathering was estimated according to Ezzaïm [7] who calculated weathering in the Beaujolais mountains on very similar soils and rocks, but, because of difficulties in measuring mineral surfaces, this author only gave a probable data range: $0.2-1.06 \mathrm{~kg} \cdot \mathrm{ha}^{-1} \cdot \mathrm{yr}^{-1} \mathrm{Ca}, 0.3-3 \mathrm{~kg} \mathrm{Mg}$ and $1.8-8 \mathrm{~kg} \mathrm{~K}$.

Water drainage composition was established annually by analysis. Drainage was estimated to be $480 \mathrm{~mm} \cdot \mathrm{yr}^{-1}$, as the difference between precipitation $(800 \mathrm{~mm})$ and evapotranspiration, the latter being estimated following the study of Mohammed Ahmed [15] at the Bonhomme Pass in the Vosges, which was at a higher altitude $(850 \mathrm{~m})$. The warmer climate of Donon forest compared with the Bonhomme Pass was taken into account and evapotranspiration was estimated to be higher $(320 \mathrm{~mm})$.

Element immobilisation in biomass was estimated using the same study, but the data were increased because wood production 
Table IV. Significant differences in mineral horizons. The 1996-1986 difference is in bold type when significant in the block interpretation. The value of 1.96 triplet standard deviation is noted only when the 1996-1986 difference in the block interpretation is significant. This value is in bold type when lower than the absolute value of the 1996-1986 difference. Exchangeable elements are expressed in $\mathrm{cmol}^{+} \cdot \mathrm{kg}^{-1}$, and available $\mathrm{P}_{2} \mathrm{O}_{5}$ in $\mathrm{g} \cdot \mathrm{kg}^{-1}$.

\begin{tabular}{|c|c|c|c|c|c|}
\hline Feature & 1986 & 1996 & $\begin{array}{l}\text { 1986-1996 } \\
\text { difference }\end{array}$ & $\begin{array}{c}\text { Triplets } \\
\text { Standard deviation } \\
\times 1.96\end{array}$ & $\begin{array}{l}\text { Significant } \\
\text { change }\end{array}$ \\
\hline \multicolumn{6}{|c|}{$0-5 \mathrm{~cm}$} \\
\hline Water $\mathrm{pH}$ & 3.9 & 4.1 & +0.20 & 0.26 & no \\
\hline $\mathrm{KCl} \mathrm{pH}$ & 3.6 & 3.3 & -0.30 & 0.15 & yes \\
\hline Exchangeable $\mathrm{Ca}$ & 0.26 & 0.31 & +0.05 & 0.18 & no \\
\hline Exchangeable $\mathrm{Mg}$ & 0.20 & 0.38 & +0.18 & 0.18 & yes \\
\hline Exchangeable K & 0.18 & 0.32 & +0.14 & 0.11 & yes \\
\hline Exchangeable $\mathrm{H}$ & 1.19 & 1.77 & +0.58 & 0.82 & no \\
\hline Exchangeable Al & 7.55 & 7.43 & -0.12 & & no \\
\hline $\begin{array}{l}\text { Bioavailable P } \\
\text { (2\% citric acid) }\end{array}$ & 0.034 & 0.048 & +0.014 & & no \\
\hline Total $\mathrm{Pb}$ & 67.0 & 97.2 & +30.2 & 21.9 & yes \\
\hline Total Zn & 67.3 & 73.8 & +13.4 & 7.79 & yes \\
\hline \multicolumn{6}{|c|}{$8-18 \mathrm{~cm}$} \\
\hline Water $\mathrm{pH}$ & 4.3 & 4.5 & +0.20 & 0.30 & no \\
\hline $\mathrm{KCl} \mathrm{pH}$ & 3.9 & 3.9 & 0 & & no \\
\hline Exchangeable $\mathrm{Ca}$ & 0.16 & 0.10 & -0.06 & 0.04 & yes \\
\hline Exchangeable $\mathrm{Mg}$ & 0.08 & 0.18 & +0.10 & 0.14 & no \\
\hline Exchangeable $\mathrm{K}$ & 0.11 & 0.15 & +0.040 & & no \\
\hline Exchangeable $\mathrm{H}$ & 0.53 & 0.17 & -0.36 & 0.23 & yes \\
\hline Exchangeable Al & 5.36 & 5.03 & -0.33 & & no \\
\hline $\begin{array}{l}\text { Bioavailable } P \\
\text { (2\% citric acid) }\end{array}$ & 0.021 & 0.025 & +0.004 & & no \\
\hline \multicolumn{6}{|c|}{$25-35 \mathrm{~cm}$} \\
\hline Water $\mathrm{pH}$ & 4.5 & 4.5 & 0 & & no \\
\hline $\mathrm{KCl} \mathrm{pH}$ & 4.1 & 4.2 & +0.10 & 0.06 & yes \\
\hline Exchangeable $\mathrm{Ca}$ & 0.11 & 0.08 & -0.03 & 0.05 & no \\
\hline Exchangeable $\mathrm{Mg}$ & 0.05 & 0.08 & +0.03 & 0.06 & no \\
\hline Exchangeable K & 0.09 & 0.12 & +0.03 & 0.043 & no \\
\hline Exchangeable $\mathrm{H}$ & 0.43 & 0.004 & -0.39 & 0.11 & yes \\
\hline Exchangeable Al & 4.07 & 3.71 & -0.36 & & no \\
\hline $\begin{array}{l}\text { Bioavailable } P \\
\text { (2\% citric acid) }\end{array}$ & 0.019 & 0.025 & +0.006 & & no \\
\hline
\end{tabular}

was higher in Donon forest: $5 \mathrm{t} \cdot \mathrm{ha}^{-1} \cdot \mathrm{yr}^{-1}$, compared with $2.5 \mathrm{t}$ at the Bonhomme Pass.

Element immobilisation in the increasing needle biomass was calculated on the basis of $6 \mathrm{t} \cdot \mathrm{ha}^{-1}$ of needles (dry weight) in ten years, with an element composition corresponding to the "stabilized element concentrations". When young needles develop, only part of the necessary elements come from the soil, the rest are provided by older needles. Thus, actual uptake from the soil corresponds to old needle element concentrations when they have supplied elements to younger needles. The "stabilized concentrations" were chosen as those of needles collected in the litter traps: $3 \mathrm{~g} \cdot \mathrm{kg}^{-1} \mathrm{Ca}$, and a little more for $\mathrm{Mg}$ and $\mathrm{K}$, as these elements could have been leached to varying extents by rain before collection: $0.6 \mathrm{~g} \cdot \mathrm{kg}^{-1} \mathrm{Mg}$ and $2 \mathrm{~g} \cdot \mathrm{kg}^{-1} \mathrm{~K}$.

The budget which was established from these calculations or estimations is presented in Table VI. 
Table V. Quantitative balance. This balance was drawn-up for the 1986-1996 period from soil analysis of total elements in the OL, OF and OH layers and of exchangeable elements in the mineral horizons from depths between 0 and $35 \mathrm{~cm}$.

\begin{tabular}{|c|c|c|c|c|c|c|c|c|}
\hline & \multicolumn{2}{|c|}{ Soil mass $\left(\mathrm{t} \cdot \mathrm{ha}^{-1}\right)$} & \multicolumn{2}{|c|}{$\mathrm{Ca}\left(\mathrm{kg} \cdot \mathrm{ha}^{-1}\right)$} & \multicolumn{2}{|c|}{$\operatorname{Mg}\left(\mathrm{kg} \cdot \mathrm{ha}^{-1}\right)$} & \multicolumn{2}{|c|}{$\mathrm{K}\left(\mathrm{kg} \cdot \mathrm{ha}^{-1}\right)$} \\
\hline & 1986 & 1996 & 1986 & 1996 & 1986 & 1996 & 1986 & 1996 \\
\hline OL & 14.4 & 10.0 & 34.5 & 26.2 & 4.4 & 4.1 & 10.8 & 8.3 \\
\hline $\mathrm{OF}$ & 17.7 & 26.2 & 30.4 & 37.9 & 13.8 & 27.2 & 11.0 & 27.4 \\
\hline $\mathrm{OH}$ & 72.6 & 41.0 & 33.2 & 19.8 & 143.0 & 84.6 & 96.4 & 77.2 \\
\hline Total in the organic horizons & 104.7 & 77.2 & 98.1 & 83.9 & 161.2 & 115.9 & 118.2 & 110.9 \\
\hline $0-5 \mathrm{~cm}$ & 186 & 194 & 9.7 & 10.6 & 4.5 & 8.2 & 13.1 & 22.0 \\
\hline $5-8 \mathrm{~cm}$ & 123 & 123 & 5.2 & 5.2 & 2.1 & 4.2 & 7.0 & 11.4 \\
\hline $8-18 \mathrm{~cm}$ & 385 & 385 & 12.4 & 7.3 & 3.7 & 8.2 & 16.5 & 22.1 \\
\hline $18-25 \mathrm{~cm}$ & 262 & 262 & 7.1 & 4.5 & 2.0 & 4.1 & 10.2 & 13.8 \\
\hline $25-35 \mathrm{~cm}$ & 436 & 436 & 9.6 & 6.7 & 2.6 & 4.3 & 15.3 & 21.1 \\
\hline Total in the mineral horizons & 1392 & 1400 & 44.0 & 34.3 & 14.9 & 29.0 & 62.1 & 90.4 \\
\hline Total for the whole soil & & & 142.1 & 118.9 & 176.1 & 144.9 & 180.3 & 203.3 \\
\hline 1996-1986 Balance & & & \multicolumn{2}{|c|}{-23.2} & \multicolumn{2}{|c|}{-31.2} & \multicolumn{2}{|c|}{+23.0} \\
\hline
\end{tabular}

Table VI. Estimation of inputs and outputs for the whole soil. Data and balance are expressed in $\mathrm{kg} \cdot \mathrm{ha}^{-1}$ for ten years.

\begin{tabular}{|c|c|c|c|c|c|c|c|}
\hline \multirow[t]{3}{*}{ Element } & \multicolumn{3}{|c|}{ Outputs } & \multicolumn{2}{|c|}{ Inputs } & \multirow{2}{*}{\multicolumn{2}{|c|}{$\begin{array}{l}\text { Theoretical balance } \\
\text { in the whole soil } \\
(4)+(5)-(1)-(2)-(3)\end{array}$}} \\
\hline & \multirow{2}{*}{$\begin{array}{c}\text { Drainage } \\
\text { (1) }\end{array}$} & \multirow{2}{*}{$\begin{array}{l}\text { Immobilization in wood } \\
\text { (2) }\end{array}$} & \multirow{2}{*}{$\begin{array}{c}\text { Increase in the } \\
\text { needle biomass } \\
\text { (3) }\end{array}$} & \multirow{2}{*}{$\begin{array}{l}\text { Atmospheric input } \\
\text { (precipitation } \\
\text { and dry deposition) } \\
\text { (4) }\end{array}$} & $\begin{array}{c}\text { Mineral } \\
\text { weathering } \\
(5)\end{array}$ & & \\
\hline & & & & & Probable range & Probable range & Mean \\
\hline $\mathrm{Ca}$ & 33 & 30 & 21 & 69 & 2 to 10 & -13 to -5 & -9 \\
\hline $\mathrm{Mg}$ & 28 & 6 & 3 & 15 & 3 to 30 & -19 to +8 & -5.5 \\
\hline K & 31 & 28 & 10 & 40 & 18 to 90 & -11 to +61 & +25 \\
\hline
\end{tabular}

Table VII. Theoretical and actual balance in mineral horizons. Data and balance are expressed in $\mathrm{kg} \cdot \mathrm{ha}^{-1}$ for ten years .

\begin{tabular}{|c|c|c|c|c|c|c|}
\hline \multirow[t]{2}{*}{ Element } & \multicolumn{2}{|c|}{$\begin{array}{l}\text { Theoretic balance in the whole soil } \\
\text { (Table VI) }\end{array}$} & \multirow{2}{*}{$\begin{array}{l}\text { Mineralisation in OL, OF, } \\
\text { OH, and transfer into } \\
\text { mineral horizons } \\
\text { (Tab. V) } \\
\text { (3) }\end{array}$} & \multicolumn{2}{|c|}{$\begin{array}{l}\text { Theoretical balance } \\
\text { in mineral horizons }\end{array}$} & \multirow{2}{*}{$\begin{array}{l}\text { Actual balance in } \\
\text { mineral horizons } \\
\text { Data in Table V }\end{array}$} \\
\hline & $\begin{array}{l}\text { Probable } \\
\text { range (1) }\end{array}$ & $\begin{array}{l}\text { Mean } \\
(2)\end{array}$ & & $\begin{array}{l}\text { Probable range } \\
\qquad(1)+(3)\end{array}$ & $\begin{array}{c}\text { Mean } \\
(2)+(3)\end{array}$ & \\
\hline $\mathrm{Ca}$ & -13 to -5 & -9 & 14.2 & +1.2 to +9.2 & +5.2 & -9.7 \\
\hline $\mathrm{Mg}$ & -19 to +8 & -5.5 & 45.3 & +26.3 to +53.3 & +39.8 & +14.1 \\
\hline K & -11 to +61 & +25 & 7.3 & -3.7 to +68.3 & +32.3 & +23.0 \\
\hline
\end{tabular}

This table shows that the real $\mathrm{K}$ increase (measured by soil analysis and indicated in table) was within the limits of the calculated budget interval. For $\mathrm{Ca}$ and $\mathrm{Mg}$, the real losses were much higher than the highest calculated value.

We tried to establish a balance for mineral horizons alone (Tab. VII). Element decrease in OL, OF and $\mathrm{OH}$ layers was considered to be due to the part of the mineralisation which exceeded steady state, and theoretically able to increase exchangeable elements in mineral horizons. Data were drawn from Table V. A theoretical balance for mineral horizons was calculated by adding together the elements released from all the organic layers (i.e. the absolute value of change in humus layers) 


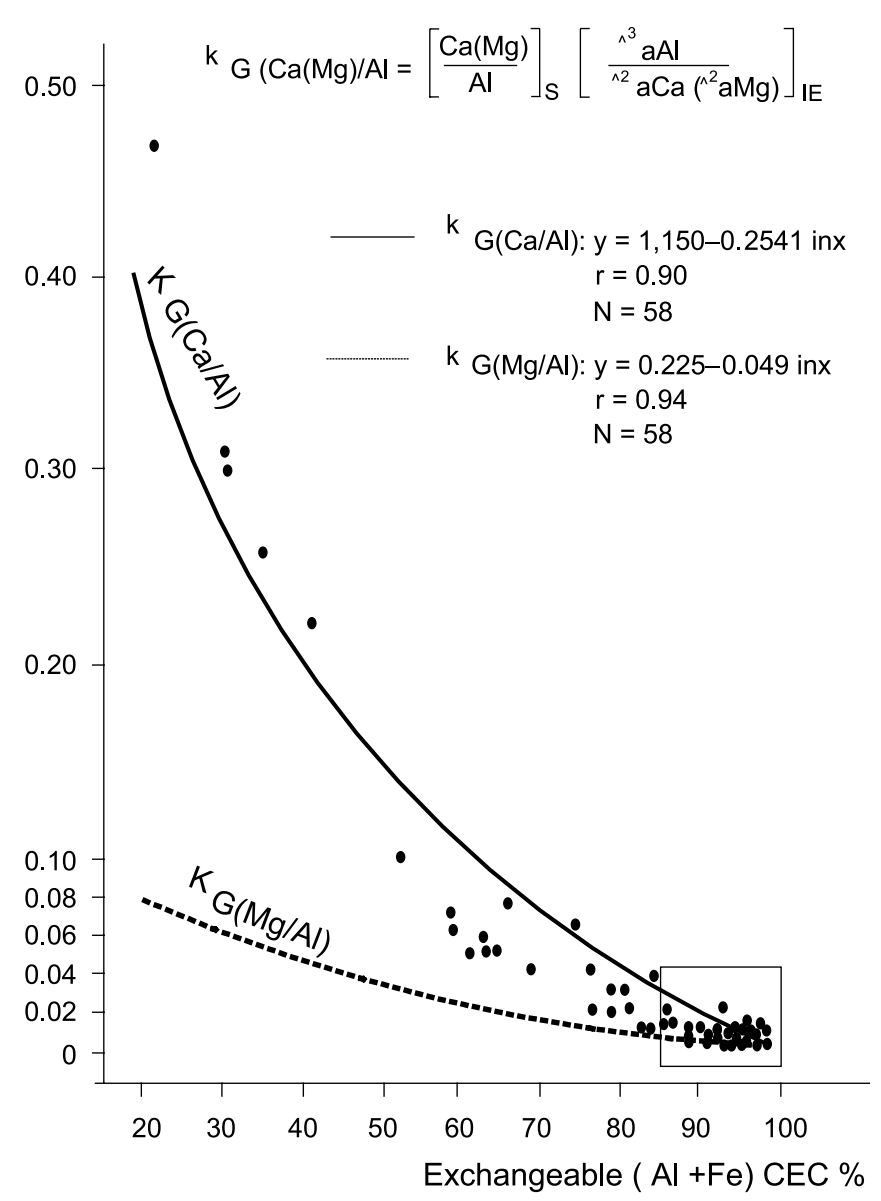

Figure 1. Effect of $\mathrm{Al}$ on $\mathrm{Ca}$ and $\mathrm{Mg}$ adsorption in mineral horizons. Evolution of Gapon's selectivity coefficients of an acidic soil, ${ }^{\mathrm{K}} \mathrm{G}(\mathrm{Ca} /$ $\mathrm{Al}$ ) and ${ }^{\mathrm{K}} \mathrm{G}(\mathrm{Mg} / \mathrm{Al})$, when saturation of $\mathrm{Al}^{3+}$ and $\mathrm{Fe}^{3+}$ increases (after [9]).

and the theoretical balance for the whole soil (i.e. the change in the whole soil $=$ change in humus layers + change in mineral horizons).

This theoretical balance was positive to varying degrees for $\mathrm{Ca}, \mathrm{Mg}$ and $\mathrm{K}$. For K, the actual balance (soil analysis) was in the calculated interval, but, for $\mathrm{Ca}$, there was a loss of $9.7 \mathrm{~kg} \cdot \mathrm{ha}^{-1}$ instead of a gain of 5.2, and, for $\mathrm{Mg}$, the actual gain, $14.1 \mathrm{~kg} \cdot \mathrm{ha}^{-1}$, was much lower than the theoretical one $\left(39.8 \mathrm{~kg} \cdot \mathrm{ha}^{-1}\right)$. A very likely explanation is that $\mathrm{Mg}$ loss in drainage water was much higher during the 1986-1993 period than the loss measured between 1993 and 1996, probably as a likely result of very active mineralisation of the organic layers in the warm summers of 1990 to 1992 . This mineralisation probably occurred at the end of the summer, when the first autumn rains wetted the soil, but, unfortunately, drainage water was not sampled before 1993. It is also possible that all the $\mathrm{Ca}$ and $\mathrm{Mg}$ which were transferred from humus layers by mineralisation were not adsorbed onto the mineral horizons.

Hildebrand [9] applied the Gapon cation exchange law to soils rich in exchangeable $\mathrm{Al}$, and showed that, when the exchange complex was very rich in exchangeable $\mathrm{Al}$, it became unable to adsorb $\mathrm{Ca}$ and $\mathrm{Mg}$ (Fig. 1).
On this basis, it was possible to explain $\mathrm{Ca}$ and $\mathrm{Mg}$ losses. When mineralised and released into the soil solution of organic layers, $\mathrm{Ca}$ and $\mathrm{Mg}$ were transferred into the mineral horizons, but they could not be adsorbed onto an Al-rich exchange complex, and were consequently lost in drainage water. Thus, the stock of exchangeable $\mathrm{Mg}$ in mineral horizons increased by $14.1 \mathrm{~kg} \cdot \mathrm{ha}^{-1}$ instead of $42.3 \mathrm{~kg} \cdot \mathrm{ha}^{-1}$. Similarly, the stock of exchangeable Ca decreased by $9.7 \mathrm{~kg} \cdot \mathrm{ha}^{-1}$ instead of increasing by $6.7 \mathrm{~kg} \cdot \mathrm{ha}^{-1}$.

These results agree well with those of the Strengbach catchment $[3,16]$ which also showed that the actual Mg loss was higher than that calculated from element balance, but, at the Donon soil experimental site, the $\mathrm{Ca}$ was also affected by the same phenomenon.

These results are also in agreement with the needle nutrient composition of the stand (N: $14.3 \mathrm{~g} \cdot \mathrm{kg}^{-1} ; \mathrm{P}: 1.5 ; \mathrm{S}: 0.92 ; \mathrm{K}$ : 5.16; Ca: 2.36; Mg: 0.85). Concentrations of N, P, S and K were satisfactory but concentrations in $\mathrm{Ca}$ and $\mathrm{Mg}$ were rather low. Investigations of spruce and white fir needle composition during dry or humid years in fertilisation experiments showed that $\mathrm{Mg}$ concentration should amount to $1.3 \mathrm{~g} \cdot \mathrm{kg}^{-1}$ in order to prevent a dramatic decrease to $0.5-0.7 \mathrm{~g} \cdot \mathrm{kg}^{-1}$ during dry years [1].

\section{CONCLUSION}

These results are firstly a good illustration of the fact that acidification, in the sense of $\mathrm{pH}$ and base saturation decrease, may be low, while loss of ANC is very high.

Secondly, it is clear that threats to future nutritional elements of forest stands may not be detected if we only consider levels of exchangeable elements at a given moment and that chemical fertility seems stable whereas the soil is losing important quantities of $\mathrm{Ca}$ and $\mathrm{Mg}$ from the organic horizons.

Thirdly, it is clear that, in very acidic soils, the loss of base cations, namely $\mathrm{Ca}$ and $\mathrm{Mg}$, is not only a direct consequence of acid rain and a progressive exchange between $\mathrm{H}^{+}$and base cations, but also of periods of high humus layer mineralisation together with a high concentration of exchangeable aluminium in the mineral horizons. The role of over-saturation of mineral horizons by $\mathrm{Al}$ has been known for a long time [9]. But the role of humus layers in the loss of nutrients seems less well documented or has been interpreted differently: being mainly attributed to soluble organic acids percolating through the soil from the organic layers when the humus form is moder or dysmoder [5].

During high humus mineralisation periods such as warm summers, and probably clear felling, large quantities of cations are leached from the humus layers into mineral horizons. The inability of roots to take up such large quantities, exceeding growth needs, and the inability of Al-rich mineral horizons to adsorb $\mathrm{Ca}$ and $\mathrm{Mg}$ efficiently, lead to high losses of these elements in drainage water, whereas $\mathrm{K}$ is increasingly retained on the exchange complex [9].

Thus the interaction between climate, humus forms and over-concentration of exchangeable $\mathrm{Al}$ in mineral horizons seems to be a very important aspect of the biogeochemical cycles of $\mathrm{Mg}$ and $\mathrm{Ca}$ in acidic soils, together with acid precipitation. Deterioration of humus forms from mull into moder or dysmoder, along with soil acidification, immobilise large quantities of 
nutrients in the humus layers. As a result, these elements are lacking in the A horizon and in the mineral horizons where the roots take up nutrients, and, more seriously, are subjected to large losses when strong mineralisation of the humus, namely the $\mathrm{OH}$ layer, occurs. This phenomenon is a key mechanism in soil acidification that seems to have been underestimated until now.

Acknowledgments: Many thanks to colleagues who helped with the sampling: Claude Nys, Yves Lefèvre, Dominique Gelhaye and Daniel Imbert; to Saïd Belkacem and the INRA laboratory in Arras for mineral soil analyses, to the INRA laboratory in Bordeaux (L.E.R.M.A.V.E.) for organic horizon analyses; to Jacques Ranger for reading, criticizing and improving this paper and to Geraldine Rigou, Christine Young and Aldice Nys for correcting English. The European Union, the French Ministry for Environment, the Alsace Region and INRA contributed financially to this work.

\section{REFERENCES}

[1] Bonneau M., Fertilisation sur résineux adultes (Picea abies Karst. et Abies alba Mill.) dans les Vosges : composition foliaire en relation avec la défoliation et le jaunissement, Ann. Sci. For. 50 (1993) 159-175.

[2] Brun J.J., Étude de quelques humus forestiers aérés acides de l'Est de la France. Critères analytiques, classification morphologique, Thèse de Doctorat $3^{\mathrm{e}}$ cycle, Université de Nancy I, 1988.

[3] Dambrine E., Pollier B., Poszwa A., Ranger J., Probst A., Viville D., Biron P., Granier A., Wieder R.K. (Eds.), Evidence of current soil acidification in spruce stands in the Vosges mountains - North eastern France, Water, Air Soil Pollut. 105 (1998) 43-52.

[4] Dambrine E., Prevosto B., Flux des éléments minéraux dans un écosystème forestier d'altitude soumis à la pollution atmosphérique, relation avec le dépérissement. Rapport scientifique DEFORPA, 1988, Nancy.

[5] Duchaufour P., Introduction à la Science du sol. Sol, végétation, environnement, Dunod, Paris, 2001.

[6] Dupouey J.L., Thimonier A., Lefèvre Y., Le Tacon F., Bonneau M., Dambrine E., Poszwa A., Landmann G., Désaturation et enrichissement en azote des sols forestiers du Nord-Est de la France au cours des dernières décennies, Rev. For. Fr. L (1988) 391-402.

[7] Ezzaïm A., Intérêt de la mesure du flux d'éléments issu de l'altération des minéraux du sol dans le calcul des bilans minéraux d'un écosystème forestier. Le cas des plantations de Douglas dans le Beaujolais (France), Thèse de Doctorat, Sciences de la Terre, Université Henri Poincaré, 1997, Nancy-I.
[8] Falkengreen-Grerup U., Effects of long-term storage on some chemical properties of forest soil samples, Ecol. Bull. 44 (1995) $129-132$.

[9] Hildebrand E.E., Zustand und Entwicklung der Austauscheigenschaften von Mineralböden an Standorten mit erkrankten Waldbestand, FowCbl. 105 (1986) 60-76.

[10] Hovman M.F., Bille-Hansen J., Sheppard L.J., Cape J.N., Atmospheric input to Danish spruce forests and effects on soil acidification and forest growth based on 12 years measurements, Water Air Soil Pollut. 106 (1999) 75-88.

[11] Jabiol B., Brêthes A., Ponge J.F., Toutain F., Brun J.J., L'humus sous toutes ses formes, ENGREF, Nancy, 1995.

[12] Kreutzer K., Beier C., Bredemeier M., Planck K., Cummings T., Farrell E.P., Lammersdorf N., Rasmussen L., Rothe A., Weiss T., Xu Y.J., De Visser P.H., Wright R.F. (Eds.), Atmospheric deposition and soil acidification in five coniferous forest ecosystems: a comparison of the control plots of the EXMAN sites, For. Ecol. Manage. 101 (1998) 125-142.

[13] Lefèvre Y., Essai de mise en évidence d'une évolution récente du $\mathrm{pH}$ et de la teneur en cations basiques de quelques sols forestiers des Vosges (nord-est de la France), Ann. Sci. For. 54 (1997) 483492.

[14] Lindstrom U.S., Nyberg L., Danielsson R., Andersson M., van Hees P.A.W., Forest soil monitoring on the regional scale, Warmland, Sweden, Ambio 27 (1998) 551-556.

[15] Mohammed Ahmed D., Rôle du facteur édaphique dans le fonctionnement bio-géochimique et l'état de santé de deux pessières vosgiennes. Effet d'un amendement calco-magnésien, Thèse de Doctorat, Université Henri Poincaré, Nancy I, 1992.

[16] Poszwa A., Dambrine E., Pollier B., Fichter J., Mise en évidence directe de l'acidification d'un sol forstier à Aubure (bassin versant du Strengbach, Haut-Rhin, France, Écologie 29 (1998) 407-410.

[17] Raubuch M., Beese F., Bolger T., Andersson J.M., Berg M.P., Couteaux M.M., Ineson P., McCarthy F., Splatt P., Verhoef H.A., Willison T., Acidifying processes and acid-base reaction in forest soils reciprocally transplanted along European transect with increasing pollution, Biogeochemistry 41 (1998) 71-88.

[18] Ranger J., Augusto L., Impact of tree species on soil solutions in acidic conditions, Ann. For. Sci. 58 (2001) 47-58.

[19] Raulund-Rasmussen K., Larsen J.B., Causes and effects of soil acidification in forests, with particular reference to the effects of air pollution and silvicultural practices, Dansk Skovbrugs Tidsskrift 75 (1990) 1-41.

[20] Tamm C.O., Acidification research in Sweden - national and international perspectives, Ecol. Bull. 44 (1995) 11-16.

[21] Tamm C.O., Hallbäcken L., Changes in soil acidity in two forest areas with different acid deposition $1920 \mathrm{~s}$ to $1980 \mathrm{~s}$, Ambio 17 (1988) 56-61.

[22] Van Bremen N., Driscoll C.T., Mulder J., Internal deposition and internal proton sources in acidification of soils and waters, Nature 37 (1984) 599-604. 